\title{
PENGARUH PENERAPAN MODEL PEMBELAJARAN STUDENT TEAM ACHIEVEMENT DIVISIONS (STAD) TERHADAP HASIL BELAJAR IPA SISWA KELAS VIII SMP SANTO ALOYSIUS BANDUNG
}

\author{
A. T. Daga ${ }^{1 *}$, Yoksiana \\ ${ }^{1}$ Program Studi Pengembangan Kurikulum Universitas PendidikanIndonesia, Bandung, Indonesia \\ ${ }^{2}$ SMP Santo Aloysius, Bandung, Indonesia \\ Author: agus_daga@yahoo.com
}

\begin{abstract}
Abstrak. Tujuan penelitian ini adalah mengetahui perbedaan hasil belajar IPA siswa kelas VIII dengan menggunakan model pembelajaran Student Team Achievement Divisions (STAD) dan model pembelajaran konvensional. Penelitian ini merupakan penelitian kuantitatif dengan metode kuasi eksperimen. Sumber data penelitian ini adalah siswa kelas VIII D dan VIII E SMP Santo Aloysius Bandung. Pengumpulan data menggunakan instrumen tes. Analisis data dilakukan untuk menentukan nilai rata-rata, persentase ketuntasan kelas, dan uji hipotesis. Hasil penelitian menunjukan bahwa nilai rata-rata pre-test kelas eksperimen adalah 11 dan kelas kontrol adalah 10. Nilai rata-rata post-tes kelas kontrol adalah 81 dan kelas eksperimen adalah 87. Persentase ketuntasan kelas kontrol adalah $83 \%$ dan kelas eksperimen adalah $100 \%$. Hasil uji statistik diperoleh harga $t=2.058, d b=47$ dan sig. (2-tailed) atau $p$-value $=0.045 / 2=0.023<0.05$, atau HO ditolak. Hasil uji statistik tersebut menunjukan adanya perbedaan skor kedua kelas tersebut. Skor kelas yang diajar dengan model STAD lebih tinggi daripada skor dikelas yang diajar dengan model pembelajaran konvensional.
\end{abstract}

Kata Kunci: Pembelajaran Kooperatif, Hasil Belajar, Student Team Achievement Division

\begin{abstract}
The purpose of this research was to determine the differences in learning outcomes of natural science students in class VIII using the Student Team Achievement Divisions (STAD) learning model and quasi-experimental method. This research is a quantitative study with a quasiexperimental method. The data source of this study were students of class VIII D and VIII E of St. Aloysius Junior High School in Bandung. Data collection using test instruments. Data analysis was performed to determine the average value, the percentage of class completeness, and hypothesis testing. The results showed that the average pre-test value of the experimental class was 11 and the control class was 10. The average post-test value of the control class was 81 and the experimental class was 87 . The percentage of completeness of the class for the control class was $83 \%$ and the experimental class was $100 \%$ Statistical test results obtained $t$ value of $2.058, d b=$ 47 and sig. (2-tailed) or p-value $=0.045 / 2=0.023<0.05$, or $\mathrm{HO}$ is rejected. The results of the statistical tests show differences in the scores of the two classes. Class scores taught with the STAD model are higher than class scores taught with conventional learning models.
\end{abstract}

Keywords: Cooperative Learning, Learning Outcomes, Student Team Achievement Division

\section{PENDAHULUAN}

Pendidikan merupakan salah satu komponen yang menentukan kualitas dan kemajuan sebuah bangsa. Kemajuan suatu bangsa memiliki hubungan yang kuat dengan kualitas pendidikan yang diberikan kepada peserta didik dan masyarakat baik melalui lembaga pendidikan maupun melalui lembaga non-pendidikan. Pendidikan merupakan bantuan kepada siswa untuk mencapai potensi dirinya dalam aspek kognitif, afektif danpsikomotor. Belajar merupakan upaya siswa mendidik dirinya sendiri. Menurut Sadiman, dkk (2010) adanya perubahan tingkah laku yang menyangkut perubahan yang 
bersifat pengetahuan (kognitif) dan keterampilan (psikomotor) maupun yang menyangkut nilai dan sikap (afektif) menjadi salah satu ciri seseorang telah belajar. Proses pembelajaran yang berkualitas akan memfasilitasi siswa untuk mengeksplorasi dan meningkatkan kualitas berbagai aspek dirinya. Pemilihan dan penentuan strategi pembelajaran akan menciptakan proses pembelajaran yang efektif. Karena belajar merupakan upaya mengarahkan peserta didik melalui proses pembelajaran untuk mencapai tujuan pembelajaran yang diharapkan maka dibutuhkan strategi yang tepat karena "strategi pembelajaran adalah cara sistematis mengkomunikasikan isi pelajaran kepada siswa untuk mencapai tujuan pembelajaran tertentu" (Fatkhurrokhman, dkk, 2018).

Pembelajaran aktif dan kooperatif akan meningkatkan kualitas proses pembelajaran. Menurut Johnson et al. sebagaimana dikutip Singh and Agrawal (2011) pembelajaran kooperatif adalah alat pendidikan dengan membentuk kelompok-kelompok kecil siswa untuk bekerja bersama pemahaman meningkatkan individu, serta pembelajaran anggota kelompok. Pembelajaran kooperatif ada ketika siswa bekerja bersama untuk mencapai tujuan pembelajaran bersama. Senada dengan pendapat tersebut Felder dan Brent (dalam Ukpepi, et.al, 2016) mengartikan pembelajaran kooperatif sebagai kerjasama siswa-siswa dalam sebuah tim untuk suatu tugas dalam kondisi untuk memenuhi kriteria tertentu. Ketentuan tersebut mencakup anggota tim yang dimintai pertanggungjawaban secara individual atas penyelesaian konten yang pada gilirannya memfasilitasi penyelesaian tugas atau proyek. Eksistensi pembelajaran kooperatif dibangun oleh beberapa unsur konstruktifnya. Sedangkan, menurut Johnson and Johnson (2015) agar pembelajaran menjadi kooperatif maka lima elemen dasar harus disusun secara tepat, yaitu: adanya saling ketergantungan positif, interaksi tatap muka, akuntabilitas atau pertanggungjawaban individu, keterampilan sosial, pemrosesan kelompok (group processing).

Salah satu strategi pembelajaran yang diyakini memfasilitasi keaktifan dan kolaborasi antara siswa di kelas adalah model pembelajaran Student Team Achievement Division (STAD). Memang model STAD merupakan model pembelajaran kooperatif yang paling dalam model ini siswa dilatih menjalin kerjasama dalam satu kelompok kecil dan saling membantu dalam memecahkan masalah. Model ini Model pembelajaran STAD cukup sederhana diimplementasikan dalam proses pembelajaran untuk meningkatkan hasil belajar siswa. Slavin (2005) menyatakan bahwa pembelajaran kooperatif meningkatkan prestasi siswa jika menggabungkan dua elemen kunci yaitu tujuan kelompok dan akuntabilitas individu, kelompok diberi penghargaan berdasarkan pembelajaran individu dari semua anggota kelompok, bukan pada produk kelompok tunggal. Menurut Huda (2014) model pembelajaran STAD merupakan pembelajaran kooperatif yang di dalamnya ada beberapa kelompok kecil siswa dengan level kemampuan akademik yang berbeda-beda saling bekerja sama untuk menyelesaikan tujuan pembelajaran.

Pembelajaran konvensional yang sering diterapkan guru dalam pembelajaran IPA justru kurang menciptakan suasana belajar aktif dan kolaboratif. Menurut Sanjaya (2006) dalam pembelajaran konvensional siswa ditempatkan sebagai obyek belajar yang berperan sebagai penerima informasi secara pasif karena penyampaian pelajaran menggunakan metode ceramah, tanya jawab dan penugasan. Boleh dikatakan bahwa pembelajaran konvensional dilakukan dengan satu arah dimana siswa melakukan dua kegiatan yaitu mendengarkan dan mencatat. Senada dengan hal tersebut Nasution sebagaimana dikutip Zulyadaini (2016) menyatakan bahwa pembelajaran konvensional merupakan pembelajaran yang berpusat pada guru sehingga siswa akan pasif mendengarkan uraian guru dan semua siswa harus belajar menurut kecepatan guru, siswa hanya menerima, mencatat dan menghafal materi pelajaran. Karena itu menurut Ruseffendi pembelajaran konvensional memiliki kekhasan tertentu, misalnya lebih mengutamakan hafalan daripada pengertian, menekankan pada keterampilan berhitung, mengutamakan hasil daripada proses, dan pengajaran berpusat pada guru (Ibrahim, 
2017). Dengan demikian model pembelajaran konvensional merupakan model pembelajaran yang terpusat pada guru, mengutamakan hasil bukan proses, siswa ditempatkan sebagai objek dan bukan subjek pembelajaran sehingga siswa sulit untuk menyampaikan pendapatnya. Metode yang digunakan didominasi metode ceramah, pembagian tugas dan latihan sebagai bentuk pengulangan dan pendalaman materi ajar.

Pembelajaran IPA terpadu merupakan salah satu bidang studi yang dianjurkan untuk diaplikasikan di jenjang pendidikan dasar yaitu SD dan SMP. IPA adalah ilmu pengetahuan yang mempelajari gejala-gejala melalui serangkaian proses ilmiah yang dibangun atas dasar sikap ilmiah (Trianto, 2010). IPA atau sains merupakan ilmu yang mempelajari gejala-gejala alam yang meliputi makhluk hidup dan makhluk tak hidup atau sains tentang kehidupan dan sains tentang dunia fisik (Rahayu, Mulyani, Miswadi, 2012). Dan berdasarkan observasi yang dilakukan terhadap siswa kelas VIII di SMP Santo Aloysius Bandung diketahui bahwa pelajaran IPA dipandang sulit oleh pada siswa, terutama kesulitan memahami konten materi IPA. Selain itu dijumpai bahwa seringkali siswa kurang memahami istilah, konsep teknis yang ada dalam buku IPA ataupun dalam lembar kerja dan lembar ulangan. Hal ini dibenarkan juga oleh guru IPA bahwa ketika mengoreksi hasil pekerjaan siswa ditemukan kesalahan memahami maksud dari soal sehingga tidak menjawab ulangan dengan benar.

Kondisi pembelajaran tersebut didukung juga oleh penerapan proses pembelajaran yang kurang efektif seperti pembelajaran yang masih didominasi dengan metode ceramah, minimnya media pembelajaran, kurangnya keterlibatan siswa dalam proses pebelajaran. Hal ini membuat mata pelajaran IPA sering kurang diminati siswa sebagaimana temuan dalam penelitian Hutari, Mardiana, Suryansyah (2015) bahwa selama proses pembelajaran kurangnya minat belajar siswa terhadap pembelajaran IPA terlihat dari siswa yang mencari kesibukan lain selama proses pembelajaran, biasanya hal tersebut terjadi karena siswa merasa bosan selama proses pembelajaran, karena kegiatan belajar mengajar yang tidak menyenangkan, rasa bosan siswa dan pembelajaran yang tidak menarik terjadi karena guru hanya menjelaskan materi selama proses belajar mengajar, siswa hanya terfokus pada guru dan papan tulis, tanpa adanya hal lain yang membuat siswa merasa tertarik dan aktif dalam belajar.

Penerapan model pembelajaran yang tepat dalam proses pembelajaran akan meningkatkan keaktifan dan kolaborasi di antara peserta didik yang diharapkan dapat meningkatkan hasil belajar peserta didik. Menurut Taurina (2015) mengatakan bahwa hasil belajar digambarkan sebagai pernyataan tertulis tentang apa yang diharapkan diketahui, dipahami, dan atau dapat dilakukan siswa pada akhir periode pembelajaran. Dengan demikian dapat dikatakan bahwa hasil belajar merupakan skor atau nilai yang diperoleh siswa setelah menempuh proses pembelajaran dalam sebuah waktu pembelajaran. Senada dengan pendapat tersebut Weinert (dalam Goh, et.al, 2017) hasil belajar mengukur apakah siswa dapat mencapai kompetensi dalam pembelajaran. Aspek kompetensi terdiri dari pengetahuan faktual dan konseptual, pengetahuan metodis, kompetensi sosial dan pribadi, serta kompetensi media. Dalam konteks inilah penerapan model pembelajarn STAD sebagai strategi pembelajaran kooperatif dalam pembelajaran IPA akan meningkatkan keaktifan, dam kolaborasi yang pada giilirannya akan meningkatkan hasil belajar siswa.

\section{METODE}

Penelitian ini merupakan penelitian eksperimen tipe kuasi eksperimen. Ciri utama dari kuasi eksperimental adalah mempunyai kelompok kontrol namun tidak dapat berfungsi sepenuhnya untuk mengontrol variabel-variabel dari luar yang mempengaruhi pelaksanaan eksperimen. Karena itu penelitian kuasi eksperimen merupakan jenis penelitian yang memiliki kelompok kontrol dan kelompok eksperimen tidak dipilih secara random (Sugiyono, 2010). Peneliti menggunakan jenis penelitian kuasi eksperimen

Daga, A.T., dan Yoksiana:Pengaruh Penerapan Model Pembelajaran Student Team Achievement Divisions (Stad) Terhadap Hasil Belajar Ipa Siswa Kelas Viii Smp Santo Aloysius Bandung 
karena dalam penelitian ini terdapat variabel-varibel dari luar yang tidak dapat dikontrol oleh peneliti. Desain penelitian ini adalah non equivalent control group design sebagaimana dikatakan Stanley dan Campbell (dalam Setyanto, 2005) bahwa salah satu desain peneitian kuasi eksperimen adalah Nonequivalent Control Group Design. Penelitian ini melibatkan dua kelas yaitu kelas eksperimen dan kelas kontrol. Kedua kelas ini diberikan perlakuan yang berbeda. Untuk mengetahui hasil belajar siswa diperoleh dari tes yang dilakukan sebanyak dua kali yaitu sebelum atau pre-test dan sesudah perlakuan atau post-test. Desain penelitian kuasi eksperimen (Jaedun, 2011) seperti ditunjukkan pada gambar berikut ini.

Gambar 1.Desain Penelitian kuasi eksperimen.

\begin{tabular}{|lll|}
\hline $\mathrm{O}_{1}$ & $\mathrm{X}$ & $\mathrm{O}_{2}$ \\
\hline $\mathrm{O}_{3}$ & $\mathrm{O}_{4}$ \\
\hline
\end{tabular}

Keterangan:

$\mathrm{O}_{1}$ : Pre-test pada kelas eksperimen

$\mathrm{O}_{2}$ : Pre-test pada kelas kontrol

$\mathrm{X}$ : Perlakuan (teratment)

$\mathrm{O}_{3}$ : Post-test pada kelas eksperimen

Populasi penelitian ini adalah siswa kelas VIII SMP santo Aloysius bandung tahun ajaran 2019/2020. Sampel atau subjek penelitian ini adalah kelas VIII D sebagai kelas kontrol dan kelas VIII E sebagai kelas eksperimen. Penentuan 2 kelas ini dilakukan dengan teknik porpusive sampling berdasarkan pertimbangan guru bidang studi IPA sebagaimana dinyatakan Sudjana (2005) bahwa sampling porpuse terjadi apabila pengambilan sampel dilakukan. Hal ini juga dinyatakan oleh oleh William R., et al. :Assignment to conditions (treatment versus no treatment or comparison) is by means of self-selection (by which participants choose treatment for themselves) or administrator selection (e.g., by officials, teachers, policymakers and so on) or both of these routes" (White and Sabarwal, 2014). Kelas eksperimen mendapat perlakuan model pembelajaran kooperatif STAD, sedangkan kelompok kontrol dilakukan pembelajaran konvensional dengan metode ceramah.

Untuk mengetahui pengaruh penerapan model pembelajaran STAD maka data yang dibutuhkan adalah data hasil belajar. Teknik pengumpulan data dalam penelitian ini adalah tes hasil belajar. Tes dilakukan pada pre-test untuk mengetahui kemampuan awal siswa dan pada post-test untuk mengetahui hasil belajar siswa sesudah dilaksanakan perlakuan. Jumlah soal tes adalah 20 nomor. Jenissoaladalahpilihanganda.Data hasil tes didukung dengan observasi dilakukan terhadap guru bidang studi untuk melihat proses penerapan model pembelajaran STAD dalam melaksanakan proses pembelajaran.

Analisis data hasil tes dilakukan untuk mengetahui hasil belajar siswa, nilai ratarata kelas dan ketuntasan klasikal baik kelas eksperimen maupun kelas kontrol. Menurut Karso, dkk, (2014) analisis untuk menentukan hasil belajar siswa menggunakan formula:

$$
\mathrm{N}=\frac{\text { Jumlah Skor Perolehan }}{\text { Jumlah Skor Maksimal }} \times 100
$$

Siswa dinyatakan tuntas jika mencapak KKM mata pelajaran IPA. Selanjutnya analisis untuk menentukan nilai rata-rata kelas menggunakan formula $\mathrm{N}=\frac{\Sigma \mathrm{x}}{\mathrm{n}}$. Selanjutnya, analisis untuk menentukan presentasi ketuntasan kelas menggunakan formula:

$$
\mathrm{N}=\frac{\text { Jumlah siswa tuntas }}{\text { Jumlah seluruh siswa }} \times 100 \%
$$

Uji hipotesis (Uji kesamaan dua rata-rata) dilakukan jika data berdistribusi normal dan homogen. Uji kesamaan dua rata-rata digunakan untuk mengetahui ada tidak adanya perbedaan hasil belajar setelah diberi perlakuan antara dua buah data. HO : 
$\mu 1 \leq \mu 2$ : Hipotesis nol atau pembanding, rata-rata hasil belajar IPA setelah mengikuti model pembelajaran STAD kurang dari atau sama dengan metode ceramah. Ha : $\mu 1>\mu 2$ : Hipotesis alternatif atau kerja, rata- rata hasil belajar IPA dengan model pembelajaran STAD signifikan lebih dari rata-rata hasil belajar model pembelajaran konvensional dengan metode ceramah. Selanjutnya uji normalitas dan homogenitas data dan uji hipotesis dilakukan dengan uji Kolmogorov-Smirnov, pada aplikasi SPSS 20 version. Menurut Sudjana (2005) jika kedua data berdistribusi normal dan homogen maka uji statistik yang digunakan untuk menguji hipotesis.

Adapun tahapan-tahapan pelaksanaan penelitian ini adalah (1) Melaksanakan pretest pada kelas eksperimen dan kelas kontrol untuk mengetahui hasil belajar awal siswa sebelum diberi perlakuan; (2) melakukan analisa data pre-test yaitu uji normalitas, uji homogenitas dan uji-t pada kelas eksperimen dan kelas control; (3) pemberian perlakuan dengan menggunakan model pembelajaran STAD di kelas eksperimen dan pemberian perlakuan menggunakan model konvensional dengan metode ceramah di kelas control; (4) melakukan post-test tuntuk mengetahui kemampuan akhir siswa setelah diberi perlakuan pada kelas eksperimen dan kelas control; (5) melakukan analisis data posttest yaituuji normalitas, uji homogenitas, uji-t pada kelas eksperimen dan kelas kontrol. dari uji hipotesis ini diketahui ada atau tidaknya perbedaan model pembelajaran STAD dan model pembelajaran konvensional.

\section{HASIL DAN PEMBAHASAN}

Hasil penelitian ini memperoleh nilai rata-rata pre-test kelas eksperimen sebesar 11 dan kelas kontrol sebesar 10. Persentase ketuntasankan kelas pada kelas eksperimen dan kelas kontrol adalah $0 \%$. Setelah kedua kelas ini diberi perlakuan yang berbeda diperoleh nilai rata-rata post-test kelas ekperimen sebesar 87 dan persentase ketuntasan sebesar $100 \%$ dan nilai rata-rata post-testkelas kontrol sebesar 81 dan persentase ketuntasan kelas sebesar $83 \%$. Hasil post-test kelas eksperimen lebih besar dibandingkan dengan kelas kontrol. Hal ni menunjukan bahwa terdapat perbedaan hasil belajar IPA dengan menggunakan model pembelajaran STAD pada kelas eksperimen dan model pembelajaran pada kelas kontrol. Hasil belajar siswa pada kelas eksperimen lebih tinggi daripada hasil belajar siswa pada kelas kontrol.

Uji Normalitas Data Pre-Test Kelas Kontrol Kelas Eksperimen

Uji normalitas data pre-test kelas kontrol dan eksperimen dilakukan dengan uji Kolmogorov-Smirnov. Hasil uji normalitas data pre-test tersebut dapat dilihat pada tabel berikut ini.

Tabel 1. Data uji normalitas pre-test kelas kontrol dan eksperimen.

One-Sample Kolmogorov-Smirnov Test

\begin{tabular}{|ll|r|r|}
\hline & & Kontrol & \multicolumn{2}{|c|}{$\begin{array}{c}\text { Eksperime } \\
\text { N }\end{array}$} & 22 & 19 \\
Normal Parametersa,b & Mean & 10.4545 & 9.9474 \\
& Std. Deviation & 1.99350 & 2.24781 \\
& Absolute & .176 & .141 \\
Most Extreme & Positive & .176 & .122 \\
Differences & & -.153 & -.141 \\
Kolmogorov-Smirnov Z & Negative & .827 & .614 \\
Asymp. Sig. (2-tailed) & & .501 & .845 \\
\hline
\end{tabular}

a. Test distribution is Normal.

Daga, A.T., dan Yoksiana:Pengaruh Penerapan Model Pembelajaran Student Team Achievement Divisions (Stad) Terhadap Hasil Belajar Ipa Siswa Kelas Viii Smp Santo Aloysius Bandung 
b. Calculated from data.

Hipotesis yang diuji adalah: HO: Distribusi Normal jika probabilitas $>0.05, \mathrm{HO}$ diterima. H1: Distribusi populasi tidak normal jika probabilitas $\leq 0.05, \mathrm{HO}$ ditolak. Dari tabel 1 diatas diketahui bahwa angka Kolmogorov-Smirnov Z pre-test kelas kontrol sebesar 0.827 dan kelas eksperimen sebesar 0.845. Selanjutnya, angka Asymp. Sig. (2tailed) pre-test kelas kontrol adalah $0.501>0.05$ dan kelas eksperimen adalah $0.845>$ 0.05 atau HO diterima. Dengan demikian data pre-test pada kelas kontrol dan eksperimen berdistribusi normal.

Uji Normalitas Data Post-test Kelas Kontrol dan Eksperimen

Uji normalitas data post-test kelas kontrol dan eksperimen dilakukan dengan uji Kolmogorov-Smirnov. Hasil uji normalitas data post-test tersebut dapat dilihat pada tabel berikut ini.

Tabel 2. Data uji normalitas post-test kelas kontrol dan eksperimen.

\begin{tabular}{|l} 
One-Sample Kolmogorov-Smirnov Test \\
\begin{tabular}{|ll|r|r|}
\hline \multicolumn{1}{|c|}{} & \multicolumn{1}{|c|}{ Kontrol } & \multicolumn{1}{c|}{ Eksperimen } \\
\hline N & & 24 & 25 \\
& Mean & 81.4583 & 87.0000 \\
Most Extreme Differences & 11.08065 & 7.50000 \\
& Std. Deviation & .198 & .185 \\
Kolmogorov-Smirnov Z & Absolute & .166 & .185 \\
Asymp. Sig. (2-tailed) & Negitive & -.198 & -.175 \\
& & .968 & .923 \\
\hline
\end{tabular}
\end{tabular}

a.Test distribution is Normal.

b.Calculated from data.

Dari tabel 1 diatas diketahui bahwa angka Kolmogorov-Smirnov Z post-test kelas kontrol sebesar 0.968 dan kelas eksperimen sebesar 0.923. Selanjutnya, angka Asymp. Sig. (2- tailed) post-test kelas kontrol adalah $0.306>0.05$ dan kelas eksperimen adalah $0.361>0.05$ atau HO diterima. Dengan demikian data pre-test pada kelas kontrol dan eksperimen berdistribusi normal.

Hasil uji homogenitas data pre-test pada kelas kontrol dan eksperimen dapat dilihat pada tabel berikut ini.

Tabel 3. Data uji homogenitas pre-test kelas kontrol dan eksperimen.

Levene's Test of Equality of Error VariancesaDependent Variable: Eksperimen

\begin{tabular}{|l|l|l|l|}
\hline $\mathrm{F}$ & $\mathrm{d}$ & $\mathrm{df}$ & \multicolumn{1}{|c|}{ Sig. } \\
& $\mathrm{f}$ & 2 & \\
\hline 1.639 & & & \\
\hline
\end{tabular}

Tests the null hypothesis that the error variance of the dependent variable is equal across groups.

a. Design: Intercept + Kontrol

Dari hasil analisa tabel Levene's Test of Equality of Error Variances diperoleh $\mathrm{F}=$ $1.639 ; \mathrm{db} 1=7 ; \mathrm{db} 2=11 ;$ sig atau $\mathrm{p}$-value $=0.223>0.05$ atau H0 diterima. Dengan 
demikian data nilai pre-test mata pelajaran IPA dari kelas kontrol dan eksperimen adalah homogen.

Hasil uji homogenitas data pre-test dan post-test pada kelas kontrol dan eksperimen dapat dilihat pada tabel berikut ini.

Tabel 4.Data Uji homogenitas post-test kelas kontrol dan eksperimen.

Levene's Test of Equality of Error VariancesaDependent Variable: Eksperimen

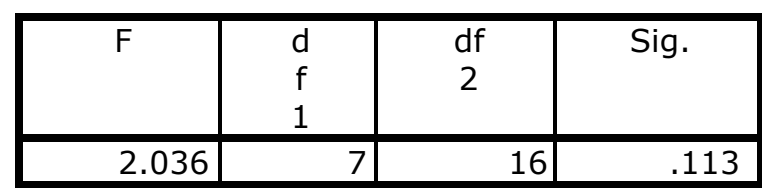

Tests the null hypothesis that the error variance of the dependent variable is equal across groups.

a. Design: Intercept + Kontrol

Dari hasil analisa tabel Levene's Test of Equality of Error Variances diperoleh $\mathrm{F}=$ 2.036; $\mathrm{db} 1=7 ; \mathrm{db} 2=16 ;$ sig atau $\mathrm{p}$-value $=0.113>0.05$ atau H0 diterima. Dengan demikian, data nilai post-test mata pelajaran IPA dari kelas kontrol dan eksperimen adalah homogen.

Hipotesis yang diuji adalah: H0: jika $\mathrm{t} \leq 0.05$ maka $\mathrm{HO}$ diterima. $\mathrm{H} 1$ : jika $\mathrm{t}>$ 0.05 maka $\mathrm{HO}$ ditolak. Kesimpulan pengujian adalah jika HO diterima, berarti tidak ada perbedaan parameter rata-rata populasi dan eksperimen. Jika HO ditolak berarti ada perbedaan parameter rata-rata populasi. Hasil pengujian hipotesis nilai post-test Kelas kontrol dan eksperimen dapat dilihat pada tabel berikut ini.

Tabel 5.Datapengujian hipotesis nilai post-test populasi.

\begin{tabular}{|l|l|c|c|c|c|}
\hline & VAR00001 & N & Mean & $\begin{array}{c}\text { Std. } \\
\text { Deviation }\end{array}$ & $\begin{array}{c}\text { Std. Error } \\
\text { Mean }\end{array}$ \\
\hline \multirow{2}{*}{ VAR00002 } & Eksperimen & 2 & 87.00 & 7.50000 & 1.50000 \\
& Kontrol & 5 & 00 & & \\
& & 2 & 81.45 & 11.08065 & 2.26183 \\
\hline
\end{tabular}

Berdasarkan tabel 5 di atas tampak bahwa rata-rata skor IPA kelas yang menggunakan model STAD adalah 87.00, dan standar deviasi 7.50 serta model konvensional sebesar 81.45 dan standar deviasi 11.08. Hal ini berarti bahwa secara deskriptif skor IPA kelas yang menggunakan model STAD lebih tinggi dan lebih konsisten daripada kelas yang menggunakan model konvensional.

Daga, A.T., dan Yoksiana:Pengaruh Penerapan Model Pembelajaran Student Team Achievement Divisions (Stad) Terhadap Hasil Belajar Ipa Siswa Kelas Viii Smp Santo Aloysius Bandung 
Tabel 6. Data independent samples test.

\begin{tabular}{|c|c|c|c|c|c|c|c|c|c|}
\hline & \multirow{2}{*}{\multicolumn{2}{|c|}{$\begin{array}{c}\text { Levene's } \\
\text { Test for } \\
\text { Equality } \\
\text { of }\end{array}$}} & \multicolumn{7}{|c|}{$\begin{array}{l}\text { t-test for } \\
\text { Equality of } \\
\text { Means }\end{array}$} \\
\hline & & & & & & & & & \\
\hline & $F$ & Sig. & \multirow[t]{2}{*}{$\mathrm{t}$} & \multirow[t]{2}{*}{$\mathrm{df}$} & \multirow[t]{2}{*}{$\begin{array}{l}\text { Sig. } \\
(2- \\
\text { tailed })\end{array}$} & \multirow[t]{2}{*}{$\begin{array}{l}\text { Mean } \\
\text { Differen } \\
\text { ce }\end{array}$} & \multirow[t]{2}{*}{$\begin{array}{l}\text { Std. } \\
\text { Error } \\
\text { Differe } \\
\text { nce }\end{array}$} & \multicolumn{2}{|c|}{$\begin{array}{c}95 \% \\
\text { Confidence } \\
\text { Interval of } \\
\text { the } \\
\text { Difference }\end{array}$} \\
\hline & & & & & & & & $\begin{array}{c}\text { Low } \\
\text { er }\end{array}$ & Upper \\
\hline $\begin{array}{l}\text { Equal } \\
\text { variances } \\
\text { assumed }\end{array}$ & $\begin{array}{l}9 \\
96\end{array}$ & .323 & 2.058 & 47 & $\begin{array}{l}.0 \\
45\end{array}$ & $\begin{array}{c}5.541 \\
67\end{array}$ & $\begin{array}{l}2.69 \\
307\end{array}$ & $\begin{array}{c}.123 \\
91\end{array}$ & $\begin{array}{c}10.95 \\
942\end{array}$ \\
\hline $\begin{array}{l}\text { Equal } \\
\text { variances } \\
\text { not assumed }\end{array}$ & & & 2.042 & $\begin{array}{l}40 . \\
224\end{array}$ & $\begin{array}{l}.0 \\
48\end{array}$ & $\begin{array}{c}5.541 \\
67\end{array}$ & $\begin{array}{l}2.71 \\
401\end{array}$ & $\begin{array}{c}.057 \\
39\end{array}$ & $\begin{array}{c}11.02 \\
594\end{array}$ \\
\hline
\end{tabular}

Berdasarkan tebal 6, pada kolom equal variances assumed dan baris Levene's test for Equality variances diperoleh $F=0.996$ dengan angka sig atau $p$-value $=0.323>$ 0.05 , yang berarti varians kedua kelas sama atau homogen. Karena varians data homogen maka dipilih kolom Equal variances assumed dan pada baris t-test for Equality Means diperoleh harga $\mathrm{t}=2.058, \mathrm{db}=47$ dan sig. (2-tailed) atau $\mathrm{p}$-value $=0.045 / 2=$ $0.023<0.05$, atau HO ditolak. Artinya, ada perbedaan kelas eksperimen dan kelas kontrol. Dengan demikian, hipotesis yang diajukan teruji oleh data, sehingga disimpulkan bahwa skor kelas eksperimen yang diajar dengan model pembelajaran STAD lebih tinggi daripada siswa dikelas kontrol yang diajar dengan model pembelajaran konvensional.

Permasalahan yang dibahas dalam penelitian ini adalah apakah ada perbedaan hasil belajar IPA siswa kelas VIII dengan menggunakan model pembelajaran STAD dan model pembelajaran konvensional di SMP Santo Aloysius Bandung tahun ajaran 2019/2020. Hasil penelitian ini menunjukan bahwa ada perbedaan, dimana hasil belajar siswa yang yang dalampembelajaran menggunakan model pembelajaran STAD lebih tinggi daripada siswa yang mengggunakan model konvensional.

Pembelajaran di kelas eksperimen menggunakan STAD. Dan menurut Santi Utami sepertidikutipCahyanto (2017) model pembelajaran STAD dapat mengatasi permasalahan pembelajaran di kelas karena ide utama pembelajaran STAD adalah memotivasi siswa agar saling membantu dalam memahami sebuah materi pelajaran dan saling membantu dalam menyelesaikan masalah. Hal ini juga ditegaskan karenaitu Jhonson sebagaimanadikutipAriani dan Agustini (2018)menyatakan bahwa tujuan pokok pembelajaran kooperatif adalah memaksimalkan belajar siswa untuk peningkatan prestasi akademik dan pemahaman baik secara individu maupun kelompok.

Kegiatan pembelajaran dimana siswa difasilitasi untuk bekerjasama dalam menyelesaikan tugas-tugas pembelajaran akan lebih memaksimalkan kemampuan siswa untuk mencapai hasil belajar yang lebih baik. Hal ini juga diakui oleh Depdiknas seperti dikutip Pramono (2008) bahwa ketika siswa bekerja sama dan berdiskusi menyelesaikan tugas dalam kelompok yang ditentukan dalam pembelajaran STAD maka siswa yang berprestasi lebih tinggi dan lebih rendah akan sama-sama diuntungkan. Siswa berprestasi lebih rendah memperoleh bantuan khusus dari teman sebaya, sehingga siswa tersebut dapat merasa terbantu dalam memahami materi. Siswa berprestasi lebih tinggi akan menjadi tutor bagi siswa berprestasi rendah dan tanpa disadari mereka telah 
melatih keterampilan berpikir kreatifnya. Menurut Widyantini, dkk (2008) model pembelajaran STAD merupakan pembelajaran kooperatif yang paling sederhana dan dapat digunakan untuk memberikan pemahaman konsep materi yang sulit kepada siswa dimana materi tersebut telah dipersiapkan oleh guru melalui lembar kerja atau perangkat pembelajaran yang lain.

Beberapa penelitian telah dilakukan dengan menerapkan model pembelajaran kooperatif tipe STAD terhadap hasil belajar siswa di antaranya Setiogohadi (dalam Ernawita, 2017) hasil penelitiannya menunjukkan bahwa proses pembelajaran dengan model STAD dapat meningkatkan aktivitas belajar siswa secara klasikal sebanyak $16.6 \%$ dari siklus I ke siklus II. Kemudian, pembelajaran dengan model STAD dapat meningkatkan hasil belajar siswa secara klasikal sebanyak $20.0 \%$ dari siklus I ke siklus II. Hal ini terjadi karena model pembelajaran STAD menekankan diskusi kelompok dimana siswa yang sudah mengerti materi yang dibahas dapat menjelaskan kepada temannya dalam kelompok yang belum mengerti atau menguasai materi.

Selain itu hasil penelitian Hasanah, Suyidno, Wati (2014) menunjukkan bahwa (1) pada pengujian komparasi t-hitung $=3,19>$ t-tabel $=2,64$ sehingga ada perbedaan antara pembelajaran kooperatif tipe STAD dengan pembelajaran konvensional terhadap hasil belajar, dan (2) pada pengujian korelasi rxy $=0,70$ dan thitung $=6,07>$ t-tabel $=$ 1,69 sehingga pembelajaran kooperatif tipe STAD dengan latihan berstruktur berpengaruh positif terhadap hasil belajar. Penelitian ini menyimpulkan bahwa pembelajaran kooperatif tipe STAD dengan $r$ berpengaruh positif terhadap hasil belajar siswa kelas VIII MTsN Banjar Selatan 2 Banjarmasin.

Kemampuan mode Ipembelajaran STAD meningkatkan hasil belajar siswa sebagaimana terlihat dari beberapa penelitian di atas dapat diterima karena menurut Melvin dan Silberman seperti dikutip Ling, Ghazali, Raman (2016) model pembelajaran STAD sebagai salah satu model pembelajaran kooperatif dapat menyatukan kelompok belajar untuk meningkatkan hasil belajar dengan pemahaman konsep dan komunikasi, bahkan mendorong siswa untuk berinteraksi secara aktif dan positif dalam suatu kelompok, siswa bertukar ide dan lebih bersedia untuk keluar dengan ide-ide baru dengan aman.

\section{KESIMPULAN}

Berdasarkan hasil penelitian danpembahasan di atasmakadapat disimpulkan bahwa: 1) Terdapat perbedaan hasil belajar pada kelas yang menggunakan model pembelajaran STAD dengan kelas yang menggunakan model pembelajaran konvensional. 2). Nilai rata-rata dan persentase ketuntasan kelas pada kelas eksperimen adalah $87 \%$ dan $100 \%$, sedangkan nilai rata-rata dan ketuntasan kelas pada kelas kontrol (kelas VIII D) adalah 81\% dan 83\%. 3) Berdasarkan Uji hipotesis: $p$-value $=0.023<0.05$, atau $\mathrm{HO}$ ditolak. Artinya, ada perbedaan antara kelas eksperimen yang proses pembelajaran menggunakan model pembelajaran STAD dengan kelas kontrol yang proses pembelajaran menggunakan model pembelajaran konvensional. Dengan demikian melalui penelitian ini dapat disimpulkan bahwa penerapan model pembelajaran STAD dapat berpengaruh signifikan terhadap hasil belajar siswa kelas VIII SMP Santo Aloysius Bandung tahun ajaran 2019/2020.Peningkatanhasilbelajartersebutkarena model pembelajaran STAD mendorong keaktifan, kerjasama, interaksi, komunitasisebaya, sertapertukaran pengetahuan diantarasiswa.Kondisi dansuasanapembelajaran yang tercipta dalam kegiatan pembelajaran STAD tersebut dapat membantu siswa mencapai hasil belajar yang lebih maksimal.

Daga, A.T., dan Yoksiana:Pengaruh Penerapan Model Pembelajaran Student Team Achievement Divisions (Stad) Terhadap Hasil Belajar Ipa Siswa Kelas Viii Smp Santo Aloysius Bandung 


\section{UCAPAN TERIMAKASIH}

Penulis berterima kasih kepada STKIP Weetebula Sumba Barat Daya NTT, Program Studi pengembangan Kurikulum SPs Universitas Pendidikan IndonesiaBandung, SMP Santo Aloysius Bandung, Priorat Pratista Kumara Warabrata Bandung atas dukungan dan kolaborasi.

\section{DAFTAR PUSTAKA}

Arbi, S. (2015). Upaya Peningkatan Hasil Belajar IPA Melalui Penerapan Model Cooperative Learning Tipe CIRC Siswa kelas VIII 2 semesteR II SMPN 1 bukit batu TA 2014/2015. Jurnal Primary Program Studi Pendidikan Guru Sekolah Dasar Fakultas Keguruan dan Ilmu Pendidikan Universitas Riau, 4 (2). Diakses dari: https://media.neliti.com/media/publications/258338upaya-peningkatan-hasil-belajar-ipa-mela-efa7f91a.pdf

Ariani dan Agustini. (2018). Model Pembelajaran Student Team Achievement Division (STAD) Dan Model Pembelajaran Teams Games Tournament (TGT): Dampak Terhadap Hasil Belajar Fisika. Science and Physics Education Journal, 1 (2), 65-77. Diakses dari: https://www.neliti.com/publications/256175/model-pembelajaran-studentteam-achievement-division-stad-dan-model-pembelajaran.

Cahyanto, Yudi Ari. (2017). Penerapan Model Pembelajaran Kooperatif Tipe STAD (Student Teams Achievment Divisions) Untuk Meningkatkan Keaktifan Dan Hasil Belajar Siswa Pada Mata Pelajaran Chasis Di Kelas XI SMKN 1 Ngawen.Skripsi. Yogyakarta: Program Studi Pendidikan Teknik Otomotif Fakultas Teknik Universitas Negeri Yogyakarta. Diakses dari: https://eprints.uny.ac.id/51007/

Ernawita. (2017). Karakteristik Model Pembelajaran Kooperatif Tipe Student Team Achievment Division (STAD) Dalam Meningkatkan Hasil Belajar Siswa. Prosiding. Seminar Nasional III Langsa-Aceh, 30 Oktober 2017, hlm. 405411. Diakses dari: http://www.conference.unsyiah.ac.id/SNMIPA/3/paper/download/890/166.

Fatkhurrokhman, M. (2018). Learning Strategies of Productive Lesson at Vocational High School in Serang City,Jurnal Pendidikan Vokasi, 8 (2), 163-172. Diakses dari: https://journal.uny.ac.id/index.php/jpv/article/download/19485/10937

Goh, et.al. (2017). Students' Experiences, Learning Outcomes And Satisfaction In eLearning, Journal of e-Learning and Knowledge Society, 13 (2), pp. 117128.Diakses dari: http://www.je-lks.com/ojs/index.php/JeLKS_EN/article/view/1298/1073

Hasanah, Suyidno, Wati. (2014). Pengaruh Pembelajaran Kooperatif Tipe Student Team Achievement Division (STAD) Dengan Latihan Berstruktur Terhadap Hasil Belajar Siswa. Berkala Ilmiah Pendidikan Fisika, 2 (1), 47-54. Diakses dari: https://ppjp.ulm.ac.id/journal/index.php/bipf/article/view/817.

Huda, M. (2014). Cooperative Learning. Yogyakarta: Pustaka Pelajar.

Hutari, Mardiana, Suryansyah. (2015). Upaya Meningkatkan Minat Belajar Siswa Pada Mata Pelajaran Ilmu Pengetahuan Alam (IPA) Dengan Model Quantum Teaching Di Kelas V Sekolah Dasar. Jurnal Pendidikan Dasar, 3 (2), 155165.

Ibrahim. (2017). Perpaduan Model Pembelajaran Aktif Konvensional (Ceramah) Dengan Cooperatif (Make A Match) Untuk Meningkatkan Hasil Belajar Pendidikan 
Kewarganegaraan. Suara Guru: Jurnal Ilmu Pendidikan Sosial, sains, dan Humaniora, 3 (2), 199-211.Diakses dari: http://ejournal.uinsuska.ac.id/index.php/suaraguru/article/view/3597

Jaedun, A. (2011). Metodologi Penelitian Eksperimen. Makalah Disampaikan Pada Kegiatan In Service I Pelatihan Penulisan Artikel IImiah, yang Diselenggarakan oleh LPMP Provinsi Daerah Istimewa Yogyakarta, Tanggal 20 - 23 Juni 2011. Yogyakarta: Puslit Dikdasmen, Lemlit UNY.

Johnson, D. W and Johnson, R. T. (2015). Cooperative Learning. Minnesota: University of Minnesota.

Karso; C, dkk. (2014). Pendidikan Matematika. Tangerang Selatan: Universitas Terbuka.

Ling, Ghazali, Raman. (2016). The effectiveness of student teams-achievement division (STAD) cooperative learning on mathematics achievement among school students in Sarikei District, Sarawak, International Journal of Advanced Research and Development, 1 (3), 17-21. Diaksesdari: https://www.researchgate.net/publication/298972734_The_effectiveness_ of_student_teams-

achievement_division_STAD_cooperative_learning_on_mathematics

Nurhasanah dan Sobandi. (2016). Minat Belajar Sebagai Determinan Hasil Belajar Siswa, Jurnal Pendidikan Manajemen Perkantoran, 1 91), 128-135. Diakses dari: https://ejournal.upi.edu/index.php/jpmanper/index

Idayani, I. P. (2018). Pengaruh Pembelajaran Kooperatif Model STAD TerhadapKeaktifan dan Hasil Belajar IPA Kelas VII SMP. Journal of Education Action Research, $2 \quad$ (1), 30-39. Diakses dari: https://ejournal.undiksha.ac.id/index.php/JEAR/article/view/13728/8563

Pramono, T. 2008. Model Pembelajaran Kooperatif Tipe STAD Untuk meningkatkan Penguasaan Konsep Cahaya dan Keterampilan Berpikir Kreatif Siswa SMP. Jurnal Penelitian Pendidikan IPA, 2 (2), 203-212.

Rahayu, Mulyani, Miswadi. (2012). Pengembangan Pembelajaran IPA Terpadu Dengan Menggunakan Model Pembelajaran Problem Base Melalui Lesson Study. Jurnal Pendidikan IPA Indonesia. 1 (1), 63-70. Diakses dari: https://journal.unnes.ac.id/nju/index.php/jpii/article/view/2015

Sadiman, dkk. (2010). Media Pendidikan: Pengertian, Pengembangan, dan Pemanfaatannya. Jakarta: Rajagrafindo Persada.

Sanjaya, W. (2006). Strategi Pembelajaran. Jakarta: Kencana Prenada Media Group.

Setyanto, A. E. (2005). Memperkenalkan Kembali Metode Eksperimen dalam Kajian Komunikasi. Jurnal IImu Komunikasi, 3 (1), 37 - 48. Diakses dari: https://ojs.uajy.ac.id/index.php/jik/article/view/239

Singh, Y. L and Agrawal, A. (2011). Introduction To Cooperative Learning, Indian Streams Research Journal, 1 (2), 1- 9. Diakses dari: https://www.researchgate.net/publication/270494960_introduction_to_cooperative_learning

Slavin, R. E. (2005). Cooperative Learning Teori, Riset dan Praktik. Terjemahan Narulita Yusron. Bandung: Nusa Media.

Sugiyono. (2010). Metode Penelitian Pendidikan Pendekatan Kuantitatif, Kualitatif, dan R \& D. Bandung: Alfabeta.

Sudjana. (2005). Metoda Statistika. Bandung: Tarsito.

Taurina, Z. (2015). Students' Motivation and Learning Outcomes: Significant Factors in Internal Study Quality Assurance System. International Journal for CrossDisciplinary Subjects in Education, 5 (4), pp. 2625-2630. Diakses dari: https://infonomics-society.org/wp-content/uploads/ijcdse/publishedpapers/special-issue-volume-5-2015/Students-Motivation-and-LearningOutcomes-Significant-Factors-in-Internal-Study-Quality-AssuranceSystem.pdf

Daga, A.T., dan Yoksiana:Pengaruh Penerapan Model Pembelajaran Student Team Achievement Divisions (Stad) Terhadap Hasil Belajar Ipa Siswa Kelas Viii Smp Santo Aloysius Bandung 
Trianto. (2010). Mendesain Model Pembelajaran Inovatif-Progresif. Jakarta: Rineka Cipta. Ukpepi,C, et.al, (2016). Cooperative Learning Strategy as Tool for Classroom Management. Advances In Multidisciplinary and Scientific Research, 2 (2), 67-76. Diakses

dari: https://www.researchgate.net/publication/326016546_Cooperative_Learni ng_Strategy_as_Tool_for_Classroom_Management

White, H and Sabarwal, S. (2014). Quasi-Experimental Design and Methods. Florence: UNICEF Office of Research - Innocenti.

Widyantini, Th., dkk. (2008). Penerapan Pendekatan Kooperatif STAD dalam Pembelajaran Matematika SMP (Paket Fasilitasi Pemberdayaan KKG/MGMP Matematika). Yogyakarta: Pusat pengembangan dan Pemberdayaan Pendidik dan tenaga kepemdidikan Matematika. Diakses dari: http://p4tkmatematika.org/fasilitasi/21-Pendekatan-Kooperatif-STAD.pdf

Zulyadaini. (2016). Perbandingan Hasil Belajar Matematika Model Pembelajaran Kooperatif Tipe Coop-Coop Dengan Konvensional. Jurnal IImiah Universitas Batanghari Jambi, 16 (1), 153-158. Diakses dari: http://ji.unbari.ac.id/index.php/ilmiah/article/view/96 